\title{
EXPERIENCES OF THE DUTCH REFORMED CHURCH (DRC) IN ZIMBABWE AND THEIR RELEVANCE FOR DEVELOPMENTS WITHIN THE DRC IN SOUTH AFRICA
}

Dion van Dyk

Moderator of the Dutch Reformed Church in Zimbabwe

\begin{abstract}
Socio-economic developments in Zimbabwe over the last few years have had a significant impact on the whole of our society. The contentious and chaotic land redistribution programme of government, a sharp decline in economic output, famine affecting more than half the population and a general deterioration in the standard of living affected all Zimbabweans. It is for good reason that a recent poll listed Zimbabwe as the country with citizens with the most pessimistic outlook in Africa. The developments in Zimbabwe also deeply affected the Dutch Reformed Church (DRC). A diminishing membership as a result of emigration and the general negative economic environment have led to the imminent dissolution (in July 2003) of the DRC Synod of Central Africa and the amalgamation with the synod of Northern Transvaal. This was the first time in the history of the DRC that a regional synod had to be disbanded.
\end{abstract}

\section{Introduction}

There is a large temptation to simplify the problems in Zimbabwe as one of governmental mismanagement and the abuse of power. Although valid, it is not the only truth about Zimbabwe. The complexities of the Zimbabwean situation must be accepted and how the church deals with unresolved issues such as the quest for a new and democratic constitution, the overhaul of the legal system, the role of the opposition in government, dealing with HIV/Aids and the poor need to be considered. Only then can the relevance of the experiences of the Dutch Reformed Church in Zimbabwe become apparent in a broader context.

The Dutch Reformed Church in Zimbabwe is a small church. At independence in 1980 it had a membership of 4500 which has shrunk to about 1500 members at present. The church is mainly Afrikaans, although English is also used in all the congregations. The present membership mainly consists of commercial farmers and others linked to the farming community. The DRC maintains strong ties with the mainly Shona speaking Reformed Church in Zimbabwe (RCZ) the Chichewa speaking Church of Central Africa Presbyterian (CCAP). The DRC is also an active member of the Zimbabwe Council of Churches (ZCC) and the Heads of Denominations (HOD).

This article is an attempt to describe how the major trends in Zimbabwe affect the church, and specifically the DRC, and the reaction to them. Hopefully the relevance will be apparent.

It must be accepted that this article is given from within the situation. I have experienced and am still experiencing first hand the political agenda of the police force; blatant racism condoned and practiced by the authorities; the effect of a major famine on a very large number of people; the total disintegration of health services especially for the 
poor; not to mention the petrol, bread and maize queues and the erosion of the spending power of pensioners. Scientific distance is still a luxury. This article can therefore only be based on observations and experiences that still have to stand the test of time. The major sources of information for this article have been newspaper articles, information distributed over electronic mail and conversations with fellow Zimbabweans.

\section{Brief overview of the current situation}

To understand the challenges the church is facing, it is important to understand the environment in which the church is operating. The following is an attempt to describe the rather unfortunate present situation in Zimbabwe.

\subsection{Economy}

A leading Zimbabwean businessman addressed a group of DRC leaders in February 2003. He presented the following statistics generally accepted by the business community:

- Zimbabwe has the fastest shrinking economy in the world. In 2003 it will experience the fifth year of contraction. The real GDP shrinkage since 1999 has been as follows :

$\begin{array}{ll}1999 & -4.00 \\ 2000 & -7.00 \\ 2001 & -8.80 \\ 2002 & -12.30 \\ 2003 \text { forecast } & -15.00\end{array}$

- Commercial agriculture shrunk from an output amounting to Z\$ 3,35 billion in 1999 to Z\$ 1.7 billion in 2002 and will be significantly lower in 2003 .

- Mining production declined from a peak of US \$ 600 million in 1996 to an estimated US \$ 360 million in 2003.

- Real wages have declined to the extent that Zimbabweans are poorer now than they were 25 years ago.

- Unemployment has reached record levels with less than one in ten people of the population currently employed.

- Inflation has steadily increased with the year on year rate increasing from $46.7 \%$ for the year to December 1998 to $198.9 \%$ for the year ending December 2002, and these are government statistics. Cumulatively over a five year period this amounts to inflation of $2164 \%$. The IMF is forecasting inflation to be $500 \%$ pa by the end of 2003 .

- The value of exports has steadily declined from US \$2,5 billion in 1996 to US \$ 1,5 billion in 2002, resulting in a critical shortage of foreign exchange. The long fuel queues attest to that. Debt servicing has come to a standstill with unpaid interest compounding problems and affects future rescue packages.

- The available exchange rate against the US \$ has declined form z \$ 55 for US \$1 to Z \$ 1500 for 1 US \$ over a period of 3 years.

All this constitutes a climate of severe hardship with the poor being affected the most.

Government refuses to accept responsibility for this sad state of affairs and claims that economic sabotage by white Zimbabweans and the British, together with a crippling drought are responsible for the economic woes of Zimbabwe.

The effects of the economic crisis on the churches have been severe. All churches find their income base threatened and struggle to survive financially. This has led to an 
unfortunate shift in focus from contributing to the whole of society to a closed shop survival mentality. This, at a time when the number of needy have increased dramatically.

Apart from its ability to reach out being limited, the DRC suddenly had to focus on helping the elderly to simply survive. With an inflation rate approaching $500 \%$ pa those on a fixed income simply have no chance. The church has to deal with unemployed members and uses various contacts and ways to try and assist. But once again, in a time of economic crisis the first instinct is to help those closest to you survive. This also led to a downsizing of the considerable involvement of the DRC to charities outside the immediate sphere of the church.

The churches in Zimbabwe were aware of an approaching economic crisis. In October 1997 the ZCC held a conference at which the DRC participated and issued a report on "Debt Crisis in Zimbabwe: A concern for Churches" (EDICESA SEMINAR SERIES 1997). Included in the report is a very enlightening article by Deprose Muchena on "Debt crisis in Zimbabwe: In search of a moral economy". In spite of arguments and proposals the basic question left unanswered was: "How do we get government to do it?" The church has not yet found a way of influencing economic policy set by government. Until then most debate and the best arguments will prove fruitless, even though economic policy and practice affect the lives of all Zimbabweans.

Since 1997 many other issues have had to be dealt with urgently by the ZCC and the whole debate on economy was unfortunately shelved.

\subsection{Land resettlement}

The whole land issue has always been highly emotional (Maposa, Jekemu \& Ruswa, 2001, p3). It has been a very important focus of the liberation struggle to reclaim land that was allegedly stolen from the forefathers. On the other hand, many white Zimbabweans were born on the land they farmed and made their living out of the land. The whole land issue is still fraught with misunderstanding, vested interests and uncertainty.

The redistribution of land was quite rightly debated within the church community of Zimbabwe. Justice and the well being of the country were at stake. In 1993 bishop S Bakare wrote a book "My Right to Land - in the Bible and in Zimbabwe. A theology of Land in Zimbabwe" in 1993. The Catholic Commission for Justice and Peace published the already mention "Land Reform in Zimbabwe" by Isaac Maposa.

The ZCC held a conference in November 2001, on where the land redistribution went wrong. This conference was sponsored by the Konrad Adenhauer Foundation. The Foundation also published "Land: Facing the Millennium Challenges in Unity and Hope" edited by Mponga, Jekemu and Ruswa in 2002, summarising the findings of that conference.

The arguments and issues can take up volumes. Basically those at stake are:

- Government started using land as a political tool and did not really redress the imbalances of the past.

- When its own laws did not suit government, they simply ignored them and at a later stage promulgated new laws retroactively.

- Violence was extensively used.

- What was publicly stated and done in reality were often two completely different things. The promises were often made for the sake of the international community. Farm evictions are still carrying on right now and the exercise did not end as promised in August 2002.

The churches in Zimbabwe face the following situation: 
- a very serious resurgence of racism. There are those who are proud that the scores with whites are being settled. The attitude of hatred from all parties is sad and frightening,

- food supplies were severely disrupted, also because the redistribution of land was carried out in a disorderly and chaotic manner,

- farmers and farm labour were displaced, some without homes to go to,

- the infrastructures of the churches were not geared to accommodate the relocation of large numbers of people,

- most important is that the whole issue of a just redistribution of land and security of tenure has not been resolved. It will remain on the agenda of churches for time to come.

The DRC in Zimbabwe has a mainly white farming membership. It identifies with the plight of farmers. Atrocities suffered in the redistribution exercise still need to be worked through by members. The church has a pastoral duty towards them.

The membership and financial base of the DRC were destroyed when white farmers were evicted from their farms. They have to rebuild their lives and for the first time since the 1920's the DRC in Zimbabwe needs external funding.

It is also unfortunately true that the DRC did not grasp the extent of the problem and the issue of justice that was at stake. In that sense the church did not educate its members and prepare them for a transition. The DRC only became a full member of the ZCC in the 1990 's and did not participate sufficiently in the national debate at that time.

Unfortunately the political polarisation of Zimbabwe has led to the church largely losing the public voice it had on the land issue from 1995 tot 2001. The agenda on land will have to be re-opened by all the churches.

\subsection{Famine, HIV/AIDS and Health Care}

Zimbabwe faces a severe famine. This is due to the chaotic land redistribution exercise that led to a drastic drop in farming production, aggravated by a severe drought and the general economic decline of the country.

Estimates vary from between five to eight million people in desperate need of food aid. The staple food, maize meal, is simply not available on the open market. It is sourced from international donors and often distributed by government and party officials who use it for political and financial gain.

Feeding the hungry is a basic responsibility of the churches. During previous droughts the churches were used in conjunction with government to distribute food especially in the remote areas. Although large international aid organisations, including Christian based ones, are involved in food distribution in Zimbabwe, it is very difficult for individual churches to obtain food and the permission to distribute it.

The DRC is involved in a feeding scheme together with the RCZ and CCAP, funded from South Africa and the Dutch and managed by an international aid agency. To be involved is possible, but food and money are needed from external sources and a lot of red tape has to be dealt with.

The DRC also tries to care especially for the destitute people, originally from Malawi and Mozambique, with no extended families in Zimbabwe. Lack of resources of both finances and food severely restrict these initiatives. 
The prevalence of HIV/AIDS is very high and estimated at about $30 \%$ of the entire population. About 700000 Aids orphans are unable to look after themselves and have no adults who can act on their behalf. They are a priority group for the care of the church.

The DRC is still lacking far behind in dealing with HIV/AIDS. Although excuses could be offered, there really are none that would satisfy those suffering and dying.

Health care is another area of great concern. The public health sector is on the verge of collapse. Apart from an ageing infrastructure that cannot be modernised for lack of funds, health care has become prohibitively expensive. Four times the monthly wage of an ordinary labourer is needed just to be admitted into hospital for treatment. Free health care does not exist any more.

Private health services and basic medication have become unaffordable for many. Up to now the DRC has dealt with the needy on an ad hoc basis. In future this will demand a concerted and coordinated effort by churches.

The old mission hospitals are still operating relatively well and are a comfort to many sick people.

\subsection{Law enforcement}

The police force carries out an agenda determined by the governing party. There are specific instances of serious criminal offences where the police simply refused to intervene and declared the crime political. This includes murder, assault, public violence, vandalising and burning of houses. The destruction of 42 houses in August 2001 belonging to whites in the Chinhoyi/Mhangura area and the looting of their contents were described as political actions beyond the jurisdiction of the police force

Since then members of the opposition have reported numerous instances of abuse, torture and assault by the police.

It is generally accepted that government purposefully appointed judges sympathetic to their cause. Other judges have been arrested on trivial charges, probably as harassment. Judge Benjamin Paradza was the first sitting judge in the history of Zimbabwe to be arrested in February 2003 and detained on what he claims to be trumped up charges. The prescribed convention in dealing with judges who are accused of crimes was not followed.

Senior members of law enforcement agencies and the judiciary have received land, sometimes contravening the directives of government itself. When a judge of the supreme court was confronted by the farmer whose land he was occupying that his actions were illegal, the judge simply said that the issue was a problem of the administrators.

The Public Order and Security Act (POSA) 2001 gave operating powers to the police to guard all public activity, the press and any opposition to government. It is implemented at the discretion of the police, often under guidance of the politicians. The vagueness of the law leaves it open to abuse.

The rights of the individual to freedom of association and expression have severely been compromised. The security police have issued warnings to outspoken clerics and a number of Anglican priests have recently been arrested.

This issue has been addressed by church leaders, but not with much success. Government simply ignores protests. The whole debate on individual rights and freedom will probably have to be taken up by at least the international church community. The ecumenical bodies should work towards that. 


\section{Justice}

\subsection{Injustice demands involvement}

The church can never be a distant player when human rights are abused and people suffer. Injustices and suffering are never theoretical, they are very real.

It is easy to make academic distinctions such as: The church cannot make policy but only react to it or the church can only intervene when an injustice has been done. It is also easy to convene another meeting about another problem. But for real people who suffer hunger, are tortured in jail, who die without medical care, all these distinctions made and resolutions proposed in luxury from a safe distance are meaningless and even harmful. A hungry person needs food, even when shared from your own table. An AIDS sufferer needs love. The political outcasts need human contact and acceptance.

We have to identify publicly with people who are suffering, and if that means to be tainted by association, so be it. The cause of justice is too often left to a select few while others enjoy the comforts of cheering them on.

The challenge is to cross the bridge between talking about injustice and doing something about it. There were and will be many conferences, and yet the church up to this day has managed to achieve very little in its quest for human rights in Zimbabwe. Recently, groups of pastors have publicly claimed their right to protest and were arrested. They were not well supported from within the churches.

The DRC has quite a good record in supporting its own members. Active support was given when farmers were jailed; members of the church publicly beaten; and farmers and their families were given 24 hours to vacate their farms. Farmers also went to a lot of trouble in trying to protect their labour force against abuse.

Unfortunately the church also cannot cater merely for the needs and desires of its own membership base. The well being of the whole of society is at stake.

\subsection{Justice must be blind}

When 42 houses belonging to white farmers were trashed and looted in August 2001, the mainline churches in Zimbabwe hardly took any notice. Twenty four white farmers were arrested without apparent reason during the same period, had to spend huge amounts on legal fees, were all acquitted and no sound was made amongst the churches that were very active and vocal during the liberation struggle of the 1960's and 1970's.

The Catholic Commission for Justice and Peace exposed the Matabeleland massacres of the mid-1980's. An estimated 25000 people were murdered and yet it seemed to pass the other churches by, including the DRC in Zimbabwe.

The South African Minister of Agriculture paid a visit to Zimbabwe in January 2003 to evaluate the land reform exercise. She commented that the only administrative mistake was that white farmers were not allowed to keep a small portion of their farms and their homesteads. It would apparently be put right. Soon. Apart from the fact that nothing was ever done about it, the willful destruction of the lives of people, often in a very cruel manner, cannot be described as "an administrative mistake" without somebody objecting. And apparently no one did.

For the church everyone must be the same. Most churches tend to deal only with those issues that directly affect them. While most churches in Zimbabwe condemned the Unilateral Declaration of Independence by Ian Smith in the then Rhodesia in 1961, the DRC in Rhodesia was the only church to officially condone it. That kind of action can never be repeated.

Justice should be blind and this is not yet the case. Churches will still have to work at it. 
2.3 Colonial heritage the cause of much pain and suffering

The biggest illusion that Zimbabwean whites had was that the past was forgotten after 20 years of independence and majority rule. The constant reassurances during the 1980 's, by government officials and especially the then Prime Minister and current State President, that the country needed the white commercial farmers only enhanced the illusion. The communal memory of past injustices was and is still very real.

The present quest for justice, and specifically the land redistribution issue, is supported by a vast majority of people. It is also seen by many as a justifiable completion of was at stake during the liberation war. There are indeed many who accept the present suffering simply as inevitable and as the birth of a truly new and just future.

I sincerely do not think that we understand the legacy of pain and hurt we left behind. And with the "we", I identify with the people who instigated the pain and suffering. In Zimbabwe the realisation dawned only recently amongst whites that their past actions were a big part of the problem, after many confrontations with the authorities, war veterans and new settlers.

The white community and those who accepted the advantages of previous dispensations without question, cannot pretend that they suddenly have no responsibility towards restitution. The desires, aspirations and emotions of those disadvantaged over many years need to be acknowledged. In fact, however unpalatable affirmative action and redistribution of wealth are, they are realities of the time to come. It needs to be understood and even accepted. And then acted upon, not avoided as if it will all go away when we close our eyes.

I talked to a black colleague about this issue and he stresses it can almost not be over emphasised. There is still a lot of communal healing needed before the past can be left behind. My colleague says that especially the scars of being treated like inferior human beings, left marks that will take time to fade.

\subsection{Land: A good principle and bad execution}

The way in which the Zimbabwean government and society dealt with the land issue and resultant economic decline was sad and very disruptive. The economic decline over the past four years speaks for itself. Agricultural production has dropped dramatically and even considering the drought, the provision of food has been severely disrupted.

This does not mean that the central issue of injustice should not be addressed. In fact, the problem will be perpetuated until properly and justly resolved.

There is a broad consensus in Zimbabwe that land needed to be redistributed on a more just basis. As stated, the mainly white commercial farming community, including the multinational companies involved in agriculture, occupied about $50 \%$ of arable land in the best farming areas. Statistics can be, and were, manipulated by all parties to further their own causes. Even so the imbalance, and specifically the racial imbalance, of land distribution could not be denied.

Rural areas became overcrowded and less and less productive. Need for additional land was acute. I specifically observed this when I was involved in a drilling operation providing water during the drought of 1992, in the remote areas that government did not even serve.

Government acquired vast tracts of land during the early 1980's. Some land was resettled, some used for farming ventures by a parastatal company, the Agricultural and Rural Development Authority (ARDA) and some land still lies derelict to this day. 
Unfortunately government ultimately dealt with the land issue motivated primarily by political gain. The whole issue was dealt with in a disorderly, unsystematic, manner with resultant chaos, unproductivity and lawlessness. The way in which Zimbabwe deals with imbalances of the past, is not to be recommended.

It is also sad that the very farmers who were encouraged by government to stay and contribute to the new Zimbabwe in 1980 are now made out to be the villains.

The way in which the Zimbabwean government handled the land redistribution exercise, must be condemned. That does not mean that the churches, and specifically the DRC, must now stop advocating the process. It simply means that justice must be done.

The DRC is now becoming a church with no vested interests in the land issue because there are hardly any farmers left amongst its membership. It still has members with expertise that can evaluate the process and make practical suggestions and contributions on how a land redistribution exercise can be properly handled.

\subsection{Democracy}

Probably every community or society regards their own way of thinking as the right and only one. Many understand by democracy a model based on the Western style of the party with most votes to be the winner and allowed to exercise its power (Chikuku \& Hungwe, 2000, p $35-40)$.

It is a simple truth that, however much we claim the right to a typical Western style of democracy, it simply has not worked in Zimbabwe. The idea of opposition as the enemy or outsider is simply too strong. That is why the classical western way of elections and electioneering regarded by us as the only way, is at least regarded with great suspicion by many in Zimbabwe. President Mbeki's proposal of a government of national unity should also be seen in this regard. He wanted the opposition to be part of government and responsible for solving the problems of the country.

Maybe the time has come for a complete rethink of an operating democracy in our peculiar society. And because the ruling party has a power base that they might not want to relinquish, they might not be that susceptible to such an idea.

The churches did a lot in initiating this process by starting the National Constitutional Assembly. It should reclaim a leading role in that process.

A properly established democracy established along the consultative lines of the initiative of the New Constitutional Assembly should be a priority of the churches. Without a functioning democracy there will be no justice. The church cannot evade this issue on the excuse of wanting to meddle in politics.

In this the churches simply have to work together under the umbrella of the ecumenical bodies.

\subsection{Legal system}

Justice and the practical execution in manner of the classical Roman and Roman Dutch law will have to be critically evalued. The government was highly critical of the restrictions of certain existing laws and merely ignored or changed them. The law enforcement officers often ignored certain laws in executing their or the politicians idea of justice. Many feel that the laws were inadequate for fulfilling the wishes of the people. Zimbabwe is one of the few, if not the only, counties in the world that makes retroactive laws on which one can actually be convicted.

Others feel that they were not offered adequate protection under the existing laws. 
Often there was total confusion of what was not merely right and wrong, but even acceptable and unacceptable.

Maybe the whole process of justly governing our society needs rethinking. The church has to play a leading role in that process.

\section{Identity}

I wanted to call this chapter the pastoral responsibility of the church and then focus on the role of the church in helping people to understand who they are. My black colleague thinks this is the most vital part of this talk. He claims it is because we are confused and often misled that we act out of character and then commit deeds that should not be part of civilised society.

Obviously the church should teach people who God is. Although self evident, this is also vital. Because a wrong perception of God in a crisis situation worsens the burden. Because then God also becomes part of the problem and not the supporting father that $\mathrm{He}$ wants to be.

It is just as vital for us to understand who we are, to accept it and be proud of it. This is not meant as something purely spiritual. We also need to accept our own backgrounds and cultures, make our own corrections where we feel it is necessary and then make our peace with whom we are. Only then can we find peace within ourselves and can we deal with others without being threatened.

I initially thought this to be true of white people or westerners who need to discover themselves as part of Africa. My colleague assures me that the black community has just as much a need to rediscover themselves. The church can be a proud facilitator in this process.

\section{Hope}

Grant me the last word as a preacher. The church carries the message of hope in any and all circumstances. The darker the surroundings, the easier the light of the gospel shines.

Without carrying that hope, all the other messages become irrelevant. And may I assure you that the DRC in Zimbabwe has kept that light shining in spite of, what was at least for us, a very dark period in our history.

\section{BIBLIOGRAPHY}

Bakare, S 1993. My right to land- in the Bible and in Zimbabwe. A Theology of Land in Zimbabwe. Zimbabwe Council of Churches Harare, Zimbabwe.

Chikuku, T \& Hungwe, A 2000. Democracy and good governance in Zimbabwe. Konrad Adenhauer Foundation and Zimbabwe Council of Churches.

EDICESA Seminar Series No.17. Debt Crisis in Zimbabwe: A concern for Churches.

Maposa, I 1995. Land Reform in Zimbabwe. Catholic Commission for Justice and Peace in Zimbabwe. 